\title{
Application of the Fuzzy Sugeno Method in a Decision Support System for Teacher Performance Assessment
}

\author{
Muhammad Rezeki ${ }^{*}$, Nursaka Putra ${ }^{2}$ \\ 1 Putra Indonesia University "YPTK" Padang, Padang, Indonesia \\ ${ }^{2}$ Catur Insan Cendekia University, Cirebon, Indonesia
}

\section{Article Information}

Article History:

Accepted by the Editor: November 24, 2021

Final Revision: December 29, 2021

Published Online: December 31, 2021

\section{Keywords}

Decision Support System

Fuzzy Sugeno

Teacher Performance Assessment

\section{Korespondensi}

E-mail: rezzhie@gmail.com*

\begin{abstract}
A B $\mathbf{S}$ T $\mathbf{R}$ A $\mathbf{C}$ T
The teacher is a professional educator who has essential duties, functions, and roles in the nation's intellectual life. In order for the functions and duties attached to the functional positions of teachers to be carried out following applicable regulations, it is necessary to assess teacher performance which ensures a quality learning process at all levels of education. Currently, teacher performance evaluation uses a manual assessment system, which causes the evaluation process to be relatively long. For this reason, a decision support system is needed that can take into account all the criteria that support decision making in order to assist, speed up and simplify the decision-making process. In determining teacher performance assessment, the method used is Fuzzy Takagi-Sugeno Kang (Fuzzy Sugeno). This method was chosen because the Fuzzy Sugeno method is a decision support model where the main input uses the basic concept of finding the weighted summation. The Fuzzy Sugeno method for assessing teacher performance uses three stages: the Fuzzification Stage, the Implication Function Stage, and the Defuzzification Stage. The level of validity with Sugeno's Fuzzy Inference Systems (FIS) method for assessing teacher performance is very good.
\end{abstract}

This is an open access article under the CC-BY-SA license (c) (7) (2)

\section{Introduction}

Decision Support System (DSS) is an information system that helps prepare unstructured and semistructured problems, using data to find solutions [1]. Currently, teacher qualifications are essential and necessary for schools, students, surrounding communities, and teachers themselves [2]. An environment where weighted decision models are used but discrete decision concepts are used will be detrimental to institutional staff [3].

The decision support system has three (3) important elements: database subsystem or data processing, model base subsystem or model processing and user interface subsystem or user display processing [4]. Decisions must be made according to predetermined criteria and must be made jointly. For this system to facilitate the decision-making process, a flexible and adaptable computer system is needed that can convert data into information, support decision-making, provide recommendations, and evaluate opportunities [5]. 
The performance evaluation system is made using a fuzzy approach from Sugeno. Fuzzy logic has the value of ambiguity or ambiguity between good and evil. In fuzzy logic theory, it is stated that the value can be a true value and a false value simultaneously [6].

\section{Method}

The stages of the research framework are very important to determine where the data that has been collected is changed from written materials, interviews or notes obtained when making observations that can be processed into a collection of data containing the opinions and understanding of the researcher. Figure 1 is a general research framework.

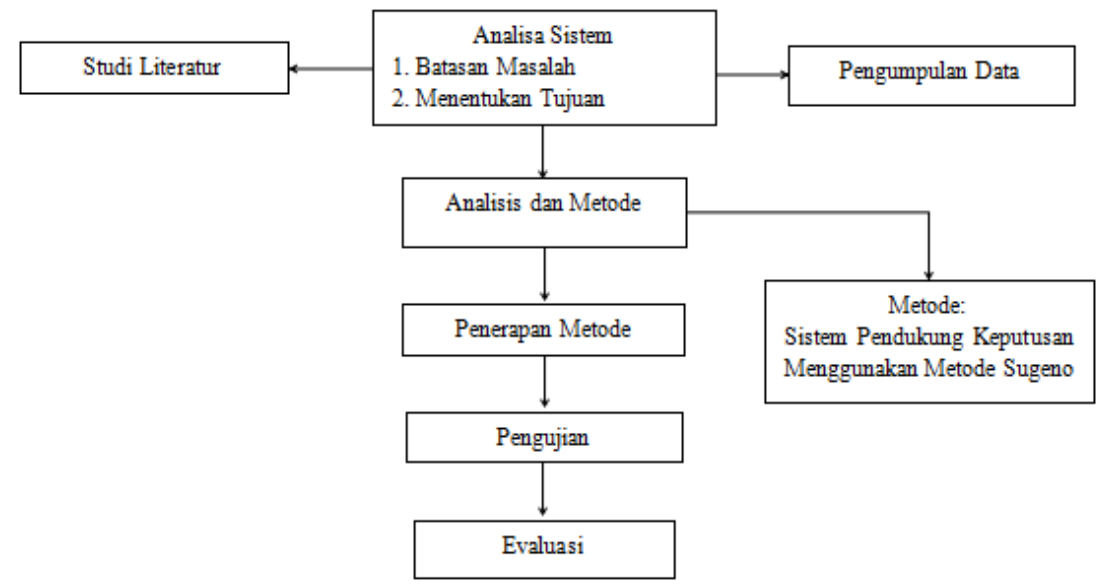

Figure 1. Research Framework for Decision Support Systems Teacher Performance Assessment System

Figure 2 is a flowchart carried out in this study.

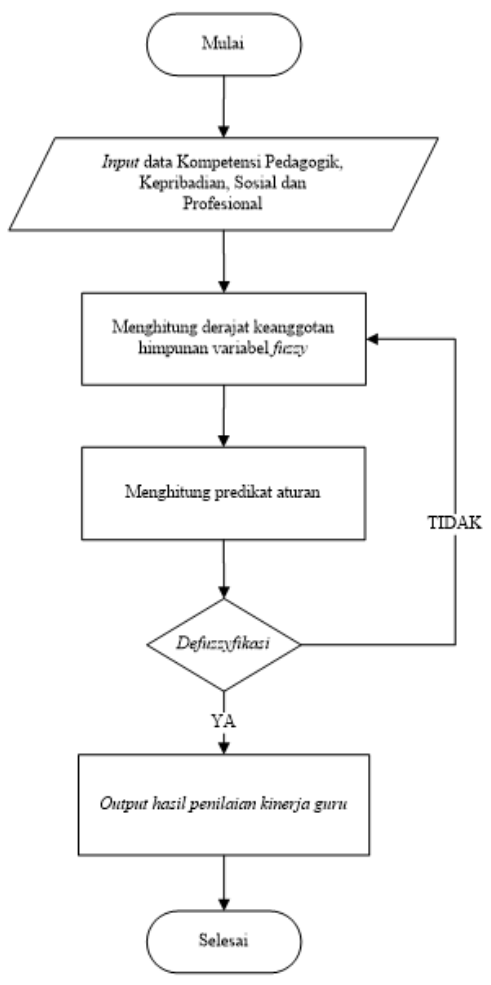

Figure 2. Flowchart of Teacher Performance Assessment Decision Support Systems Research 
This research was conducted using the Sugeno-type fuzzy approach to get the output or output on fuzzy logic. System testing is carried out in the decision support system for teacher performance assessment carried out in order to find out to what extent the Fuzzy Sugeno method can be applied to measure teacher performance.

\section{Results and Discussion}

\subsection{Analysis and Design}

In evaluating teacher performance, we often encounter several problems, including the ambiguity of superiors in assessing teachers for what is assessed in terms of subjectivity or teacher quality, so that the values given are uncertain or fuzzy. Inaccurate assessments can affect decision making, but because of the large number of teachers, the teacher assessment process will take a long time.

Analysis of the problem with the Ishikawa bone diagram (Fishbone) is used to determine the issues or problems found. This problem is based on several root causes, which can be seen in Figure 3 .

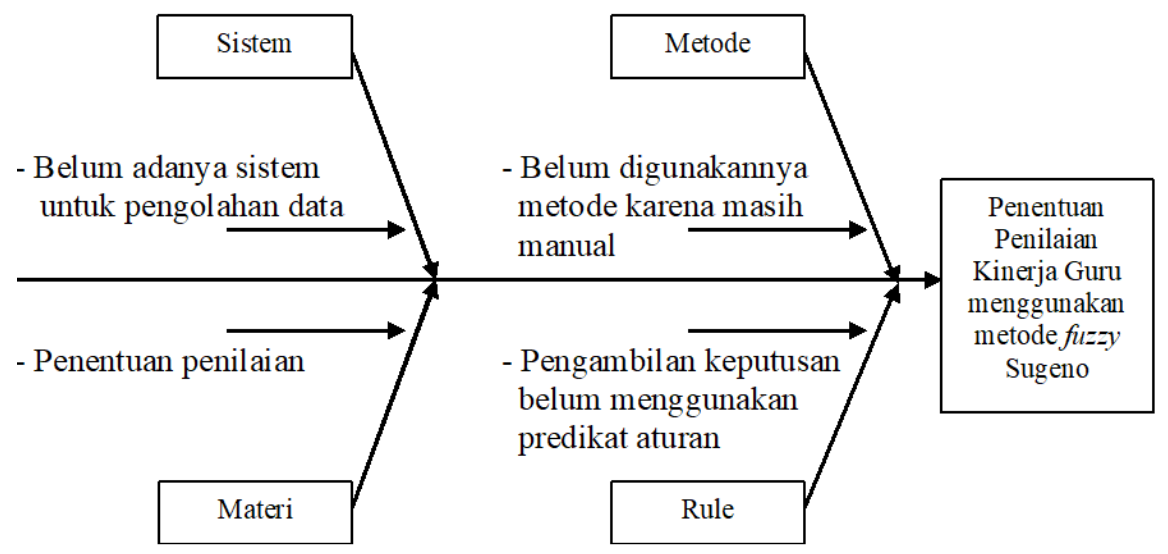

Figure 3. Ishikawa Diagram

From the specification data for teacher performance appraisal, the desired system design can be implemented based on the regulations set by the Minister of Administrative Reform and Bureaucratic Reform Number 16 of 2009 concerning Teacher Job Evaluation. Regulation on National Learning in Indonesia No. 16 of 2007 concerning learning standards and Teacher Competencies, in which there are 4 (four) skills that must be possessed by a teacher, namely pedagogic, character, social and reliable skills with 14 (fourteen) subskills according to the formula National Education Standards Agency (BNSP).

\subsubsection{Data analysis}

At this stage, data analysis is used in designing a system to be utilized as expected. The data inputted into the system are interrelated between one data and another. In order to make it easier to analyze the data will be grouped, the data are grouped based on predetermined boundaries.

The basic structure of the Fuzzy Inference system consists of: (1) a rule base containing a number of fuzzy rules that map fuzzy input values to fuzzy output values ; (2) this rule is often stated in an if-then format; (3) the information base is useful as a member of the fuzzy set for system variable values; and (4) the mechanism in fuzzy logic carry out the system inference procedure.

Identification to determine teacher performance assessment is tested by determining the variables needed for processing and analysis, where the variables or criteria that must exist are Pedagogic, Personality, Social and Professional, which will be arranged into a hierarchical structure as shown in Figure 4. 


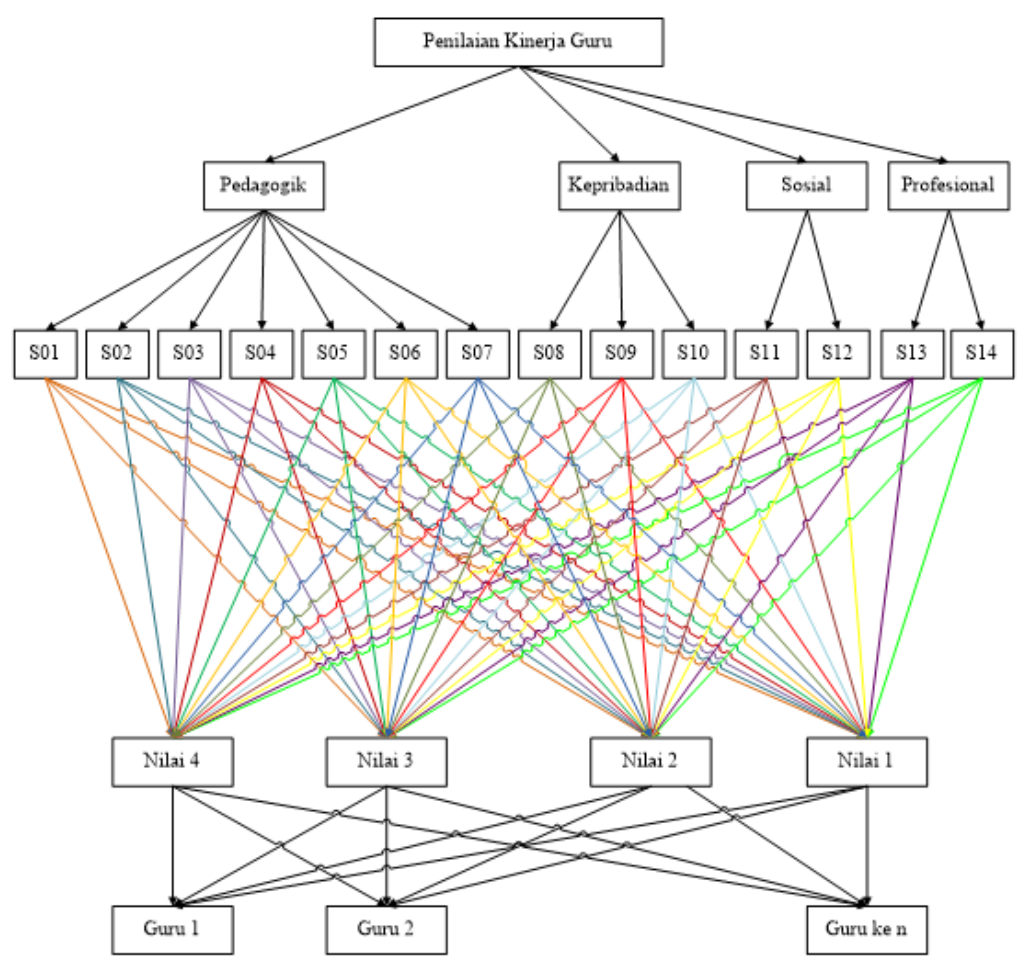

Figure 4. Hierarchical Structure of Teacher Performance Assessment

\subsubsection{Data initialization}

Initialization of this data is useful to make it easier for us to process data, Table 1 and Table 2 below are initialization of criteria, sub-criteria and teacher's name.

\section{Table 1. Initialization of Criteria and Sub-criteria}

\begin{tabular}{|c|c|c|c|c|}
\hline No. & Criteria & Sub Criteria & $\begin{array}{l}\text { Initials of } \\
\text { Sub Criteria }\end{array}$ & $\begin{array}{l}\text { Number of } \\
\text { Indicators }\end{array}$ \\
\hline 1. & & Understanding the characteristics of students. & S01 & 6 \\
\hline 2. & & $\begin{array}{l}\text { Understand learning theory and pedagogic learning } \\
\text { principles. }\end{array}$ & S02 & 6 \\
\hline 3. & C1 & Curriculum development. & S03 & 4 \\
\hline 4. & Pedagogic & Educational learning activities. & S04 & 11 \\
\hline 5. & Competence & Development of student potential. & S05 & 7 \\
\hline 6. & & Communication with students. & S06 & 6 \\
\hline 7. & & Assessment and evaluation. & S07 & 5 \\
\hline 8. & $\mathrm{C} 2$ & $\begin{array}{l}\text { Behave based on applicable rules, whether based on law, } \\
\text { religion, social and national culture. }\end{array}$ & S08 & 5 \\
\hline 9. & Personality & Shows a mature and exemplary personality. & S09 & 5 \\
\hline 10. & Competence & $\begin{array}{l}\text { Have work spirit, high responsibility towards work, proud to } \\
\text { be a teacher. }\end{array}$ & S10 & 8 \\
\hline 11. & $\mathrm{C} 3$ & Be inclusive, act objectively and non-discriminatory. & S11 & 3 \\
\hline 12. & $\begin{array}{c}\text { Social } \\
\text { Competence }\end{array}$ & $\begin{array}{l}\text { Communicate with fellow teachers, educators, parents and the } \\
\text { community. }\end{array}$ & S12 & 3 \\
\hline 13. & $\begin{array}{c}\text { C4 } \\
\text { Professional }\end{array}$ & $\begin{array}{l}\text { Understanding of theories, frameworks, and scientific thinking } \\
\text { that includes lesson modules. }\end{array}$ & S13 & 3 \\
\hline 14. & Competence & $\begin{array}{l}\text { Develop professionalism through reflective actions. } \\
\text { Amount }\end{array}$ & S14 & $\begin{array}{c}6 \\
78\end{array}$ \\
\hline
\end{tabular}


Table 2. Teacher Initialization

\begin{tabular}{|c|c|c|c|}
\hline No. & Initialization & Teacher Name & School Name \\
\hline 1. & $\mathrm{~A} 1$ & NURLIDAWATI, A.Ma & SDN 01 SARIK ALAHAN TIGO \\
\hline 2. & A2 & ZULHARNAWATI, S.Pd & SDN 01 SARIK ALAHAN TIGO \\
\hline 3. & A3 & DASMURNI, S.Pd & SDN 02 TALANG BABUNGO \\
\hline 4. & $\mathrm{~A} 4$ & NELFI ELIDA, S.Pd.I & SDN 02 TALANG BABUNGO \\
\hline 5. & A5 & FERMIATI ASWITA & SDN 03 SUNGAI ABU \\
\hline 6. & A6 & ISHAQ, S.Pd & SDN 03 SUNGAI ABU \\
\hline 7. & A7 & YULMARNIDA, S.Pd.SD & SDN 04 TALANG BABUNGO \\
\hline 8. & A8 & ERNITA KASWATI, S.Pd & SDN 04 TALANG BABUNGO \\
\hline 9. & A9 & ANI ROSWANI, S.Pd & SDN 05 TALANG BABUNGO \\
\hline 10 & A10 & EDAR HASNI, S.Pd & SDN 05 TALANG BABUNGO \\
\hline
\end{tabular}

\subsubsection{Pedagogic criteria}

Table 3 below is the pedagogic criteria possessed by the teacher.

Table 3. Pedagogic Criteria

\begin{tabular}{|c|l|}
\hline No & \multicolumn{1}{|c|}{ Criteria List } \\
\hline 1 & The teacher recognizes the learning personality of students in class. \\
\hline 2 & $\begin{array}{l}\text { The teacher confirms that all students participate in the educational process and have the same } \\
\text { opportunity to achieve success. }\end{array}$ \\
\hline 3 & $\begin{array}{l}\text { Teachers control students in learning and provide opportunities for fair learning for all students with fun } \\
\text { learning methods. }\end{array}$ \\
\hline 4 & The teacher tries to find the trigger for the deviation of students' attitudes towards other students. \\
\hline 5 & The teacher gives enthusiasm to improve students' learning abilities in overcoming their weaknesses. \\
\hline 6 & $\begin{array}{l}\text { The teacher pays attention to students with special needs so that they can participate in learning activities, } \\
\text { and do not let these students be marginalized (rejected, ridiculed, lost), underprivileged and others). }\end{array}$ \\
\hline
\end{tabular}

\subsubsection{Teacher value data}

Based on the data and research information collected, there were ten teachers from five schools in the UPT Preschool and SD Hiliran Gumanti District, the data will be analyzed using the Fuzzy Logic method which can be seen in Table 4 .

Table 4. Teacher Value Data

\begin{tabular}{|c|c|c|c|c|c|c|c|c|c|c|c|c|}
\hline No. & Criteria & Sub Criteria & A1 & A2 & A3 & A4 & A5 & A6 & A7 & A8 & A9 & A10 \\
\hline 1. & \multirow{8}{*}{ C1 Pedagogic Competence } & S01 & 2 & 3 & 3 & 4 & 3 & 3 & 3 & 2 & 4 & 3 \\
\hline 2. & & S02 & 2 & 3 & 2 & 3 & 2 & 2 & 3 & 3 & 3 & 4 \\
\hline 3. & & S03 & 2 & 3 & 2 & 3 & 2 & 3 & 3 & 3 & 3 & 3 \\
\hline 4. & & S04 & 2 & 4 & 3 & 4 & 3 & 2 & 3 & 2 & 3 & 3 \\
\hline 5. & & S05 & 2 & 3 & 2 & 3 & 3 & 2 & 3 & 3 & 4 & 3 \\
\hline 6. & & S06 & 3 & 3 & 3 & 3 & 3 & 3 & 3 & 3 & 4 & 3 \\
\hline 7. & & S07 & 2 & 4 & 2 & 3 & 3 & 2 & 3 & 3 & 4 & 3 \\
\hline 8. & & S08 & 3 & 3 & 3 & 3 & 3 & 3 & 3 & 3 & 3 & 3 \\
\hline 9. & \multirow[t]{2}{*}{ C2 Personality Competence } & S09 & 3 & 3 & 3 & 2 & 3 & 2 & 2 & 2 & 3 & 2 \\
\hline 10. & & S10 & 2 & 4 & 2 & 3 & 3 & 3 & 2 & 3 & 3 & 3 \\
\hline 11. & \multirow{2}{*}{ C3 Social Competence } & S11 & 2 & 3 & 3 & 3 & 3 & 3 & 3 & 2 & 3 & 3 \\
\hline 12. & & S12 & 3 & 3 & 3 & 3 & 3 & 3 & 3 & 3 & 3 & 3 \\
\hline 13. & \multirow{2}{*}{ C4 Professional Competence } & S13 & 2 & 3 & 2 & 4 & 3 & 2 & 2 & 3 & 4 & 3 \\
\hline 14. & & S14 & 2 & 3 & 2 & 2 & 3 & 2 & 2 & 3 & 3 & 3 \\
\hline & Amount & & 32 & 45 & 35 & 43 & 40 & 35 & 38 & 38 & 47 & 42 \\
\hline
\end{tabular}

The sub-criteria value data in Table 4 is obtained from the results of the assessment of each indicator multiplied by 2, the method of obtaining it can be seen in Table 5 below. 
Table 5. Indicator Assessment

\section{Indicator}

The teacher recognizes the learning personality of students in class.

The teacher confirms that all students participate in the educational process and have the same opportunity to achieve success.

Teachers control students in learning and provide opportunities for fair learning for all students with fun learning methods.

The teacher tries to find the trigger for the deviation of students' attitudes towards other students.

The teacher gives enthusiasm to improve students' learning abilities in overcoming their weaknesses.

The teacher pays attention to students with special needs so that they can participate in learning activities, and do not let these students be marginalized (exceptions, ridicule, inferiority complex, etc).

Total scores obtained

Maximum value of competence $=$ many indicators $\mathrm{x}$ highest value

Percentage $(\%)$ of skill points $=$ total score divided by maximum skill points multiplied by $100 \%$

Conversion of competency score $(0 \%<\times 25 \%=1 ; 25 \%<\times 50 \%=2 ; 50 \%<\times 75 \%=3$; and $75 \%<\times 100 \%=4)$

Rank
0
$(0)$
0
$(0)$
0
$1+2+2+0+0+2)=7$
$6 \times 2)=12$
$7: 12) \times 100 \%=58.33 \%$
$58.33 \%$ are in the range of
$50 \%<\times 75 \%$, so competency
1 is worth 3

\subsubsection{Determining the global weight for each criterion}

Before we determine the global weight for each criterion, the first thing to do is to form a pairwise comparison matrix (Pairwise Comparison). The results of the pairwise comparison matrix for each criterion are shown in Figure 5.

\begin{tabular}{|c|c|c|c|c|c|c|c|c|}
\hline \multicolumn{2}{|c|}{ Indikator } & 6 & 6 & 4 & 11 & 7 & 6 & 5 \\
\cline { 3 - 9 } & & $\mathrm{SO} 1$ & $\mathrm{~S} 02$ & $\mathrm{SO} 3$ & $\mathrm{~S} 04$ & $\mathrm{~S} 05$ & $\mathrm{~S} 06$ & $\mathrm{~S} 07$ \\
\hline 6 & $\mathrm{~S} 01$ & 1 & 1 & 3 & $1 / 6$ & $1 / 2$ & 1 & 2 \\
\hline 6 & $\mathrm{~S} 02$ & 1 & 1 & 3 & $1 / 6$ & $1 / 2$ & 1 & 2 \\
\hline 4 & $\mathrm{~S} 03$ & $1 / 3$ & $1 / 3$ & 1 & $1 / 8$ & $1 / 4$ & $1 / 3$ & $1 / 2$ \\
\hline 11 & $\mathrm{~S} 04$ & 6 & 6 & 8 & 1 & 5 & 6 & 7 \\
\hline 7 & $\mathrm{~S} 05$ & 2 & 2 & 5 & $1 / 5$ & 1 & 2 & 3 \\
\hline 6 & $\mathrm{~S} 06$ & 1 & 1 & 3 & $1 / 6$ & $1 / 2$ & 1 & 2 \\
\hline 5 & $\mathrm{~S} 07$ & $1 / 2$ & $1 / 2$ & $1 / 3$ & $1 / 7$ & $1 / 3$ & $1 / 2$ & 1 \\
\hline Jumlah & 11,8 & 11,8 & 23,3 & 1,97 & 8,08 & 11,8 & 17,5 \\
\hline
\end{tabular}

\begin{tabular}{|c|c|c|c|c|}
\hline \multicolumn{5}{|c|}{$c 2$} \\
\hline \multirow{2}{*}{ Indikator } & 5 & 5 & 8 \\
\cline { 3 - 5 } & & S08 & S09 & S10 \\
\hline 5 & S08 & 1 & 1 & 3 \\
\hline 5 & S09 & 1 & 1 & 3 \\
\hline 8 & S10 & 0,33 & 0,33 & 1 \\
\hline \multicolumn{2}{|c|}{ Jumlah } & 2,33 & 2,33 & 7 \\
\hline
\end{tabular}

\begin{tabular}{|c|c|c|c|}
\hline \multicolumn{4}{|c|}{ c3 } \\
\hline \multirow{2}{*}{\multicolumn{2}{|c|}{ Indikator }} & 3 & 3 \\
\hline & & $\mathrm{S} 11$ & S12 \\
\hline 3 & $\mathrm{~S} 11$ & 1 & 1 \\
\hline 3 & $\mathrm{~S} 12$ & 1 & 1 \\
\hline \multicolumn{2}{|c|}{ Jumlah } & 2 & 2 \\
\hline
\end{tabular}

\begin{tabular}{|c|c|c|c|}
\hline \multicolumn{4}{|c|}{ c4 } \\
\hline \multirow{2}{*}{\multicolumn{2}{|c|}{ Indikator }} & 3 & 6 \\
\hline & & S13 & S14 \\
\hline 3 & \$13 & 1 & 1 \\
\hline 6 & S14 & 1 & 1 \\
\hline \multicolumn{2}{|c|}{ Jumlah } & 2 & 2 \\
\hline
\end{tabular}

Figure 5. Global Weight Value of Each Criterion

From the figure, it can be concluded: (1) the comparison score for yourself (S01: S01, S02: S02, S03: S03, up to S07: S07) is worth one thing, this means that the seriousness of the argency is the same; (2) the comparison score between S01 and S05 is worth two things, this means that the score of S01 against S05 is still unclear; and (3) the comparison of S01 with $\mathrm{S} 02$ with a value of 1 can be explained that the importance of S01 to S02 is the same.

The next step is to add up the weighted values based on importance. The first step is done by dividing cells based on the number of existing columns. 
Coloum S01 $=(1: 11.83)=0.08$

Coloum S02 $=(1: 11.83)=0.08$

and so on.

Then look for the total of each row and do the division to the sub-criteria elements and when the results are added up will get a value of 1 (one). By dividing each cell by the number in its column, it can be seen in Figure 6.

\begin{tabular}{|c|c|c|c|c|c|c|c|c|c|c|c|}
\hline \multicolumn{9}{|c|}{$\mathrm{C} 1$} & & & \\
\hline & S01 & $\mathrm{S} 02$ & $\mathrm{~S} 03$ & \begin{tabular}{|l|l} 
S04 \\
\end{tabular} & S05 & S06 & S07 & BP & \\
\hline S01 & 0,08 & 0,08 & 0,13 & 0,08 & 0,06 & 0,08 & 0,11 & 0,09 & & & \\
\hline $\mathrm{S} 02$ & 0,08 & 0,08 & 0,13 & 0,08 & 0,06 & 0,08 & 0,11 & 0,09 & \\
\hline $\mathrm{S} 03$ & 0,03 & 0,03 & 0,04 & 0,06 & 0,03 & 0,03 & 0,03 & 0,04 & & S08 & \\
\hline S04 & 0,51 & 0,51 & 0,34 & 0,51 & 0,62 & 0,51 & 0,4 & 0,48 & S08 & 0,43 & \\
\hline S05 & 0,17 & 0,17 & 0,21 & 0,1 & 0,12 & 0,17 & 0,17 & 0,16 & 509 & 0,43 & \\
\hline S06 & 0,08 & 0,08 & 0,13 & \begin{tabular}{|l}
0,08 \\
\end{tabular} & \begin{tabular}{|l|}
0,06 \\
\end{tabular} & 0,08 & 0,11 & 0,09 & $\$ 10$ & 0,14 & \\
\hline S07 & 0,04 & 0,04 & 0,01 & 0,07 & 0,04 & 0,04 & 0,06 & 0,04 & Jumlah & & \\
\hline Jumlah & 1 & 1 & 1 & 1 & 1 & 1 & 1 & 1 & Jumlah & 1 & \\
\hline & \multicolumn{5}{|c|}{ C3 } & \multirow{2}{*}{\multicolumn{6}{|c|}{$\mathrm{C} 4$}} \\
\hline & & & $\$ 11$ & \multirow{2}{*}{$\$ 12$} & \multirow{2}{*}{ BP } & & & & & & \\
\hline & & & & & & \multirow{2}{*}{\multicolumn{2}{|c|}{ S13 }} & S13 & S14 & $\mathrm{BP}$ & \\
\hline & S1. & 11 & 0,5 & 0,5 & 0,5 & & & 0,5 & 0,5 & 0,5 & \\
\hline & S1 & 12 & 0,5 & 0,5 & 0,5 & \multicolumn{2}{|c|}{ S14 } & 0,5 & 0,5 & 0,5 & \\
\hline & $\mathrm{Jn}$ & $\mathrm{ml}$ & 1 & 1 & 1 & \multicolumn{2}{|c|}{$\mathrm{Jm} 1$} & 1 & 1 & 1 & \\
\hline
\end{tabular}

Figure 6. Value of Weighting Based on the Scale of Interest

The next step is to calculate the maximum value of lamda (max) which is often also called eigenvalue , this is obtained by finding the total value of the multiplication of the weights of the added interest scale in the paired matrix comparison column. The results can be seen in Figure 7.

\begin{tabular}{|c|c|c|c|c|c|c|c|c|c|c|c|}
\hline \multicolumn{12}{|c|}{$\mathrm{Cl}$} \\
\hline Subkriteria & $\begin{array}{c}\text { Bobot } \\
\text { Prioritas }\end{array}$ & Al & A2 & A3 & A4 & A5 & A6 & A7 & A8 & A9 & $\mathrm{Al0}$ \\
\hline S01 & 0,09 & 2 & 3 & 3 & 4 & 3 & 3 & 3 & 2 & 4 & 3 \\
\hline $\mathrm{S} 02$ & 0,09 & 2 & 3 & 2 & 3 & 2 & 2 & 3 & 3 & 3 & 4 \\
\hline 503 & 0,04 & 2 & 3 & 2 & 3 & 2 & 3 & 3 & 3 & 3 & 3 \\
\hline 504 & 0,48 & 2 & 4 & 3 & 4 & 3 & 2 & 3 & 2 & 3 & 3 \\
\hline S05 & 0,16 & 2 & 3 & 2 & 3 & 3 & 2 & 3 & 3 & 4 & 3 \\
\hline 506 & 0,09 & 3 & 3 & 3 & 3 & 3 & 3 & 3 & 3 & 4 & 3 \\
\hline S07 & 0,04 & 2 & 4 & 2 & 3 & 3 & 2 & 3 & 3 & 4 & 3 \\
\hline \multicolumn{2}{|c|}{ Nilai Rata-rata } & 2,07 & 3,49 & 2,64 & 3,54 & 2,84 & 2,20 & 2,97 & 2,40 & 3,35 & 3,06 \\
\hline
\end{tabular}

\begin{tabular}{|c|c|c|c|c|c|c|c|c|c|c|c|}
\hline \multicolumn{12}{|c|}{$\mathrm{C} 2$} \\
\hline Subkriteria & $\begin{array}{c}\text { Bobot } \\
\text { Prioritas }\end{array}$ & Al & A2 & A3 & A4 & A5 & A6 & A7 7 & A8 & A9 & Al0 \\
\hline S08 & 0,43 & 3 & 3 & 3 & 3 & 3 & 3 & 3 & 3 & 3 & 3 \\
\hline SO9 & 0,43 & 3 & 3 & 3 & 2 & 3 & 2 & 2 & 2 & 3 & 2 \\
\hline S10 & 0,14 & 2 & 4 & 2 & 3 & 3 & 3 & 2 & 3 & 3 & 3 \\
\hline \multicolumn{2}{|c|}{ Nilai Rata-rata } & 2,86 & 3,14 & 2,86 & 2,57 & 3,00 & 2,57 & 2,43 & 2,57 & 3,00 & 2,57 \\
\hline
\end{tabular}

\begin{tabular}{|c|c|c|c|c|c|c|c|c|c|c|c|}
\hline \multicolumn{12}{|c|}{$\mathrm{C} 3$} \\
\hline Subkriteria & $\begin{array}{c}\text { Bobot } \\
\text { Prioritas }\end{array}$ & $\mathrm{Al}$ & $\mathrm{A} 2$ & A3 & A4 & A5 & A6 & A7 & A8 & A9 & $\mathrm{Al0}$ \\
\hline S11 & 0,5 & 2 & 3 & 3 & 3 & 3 & 3 & 3 & 2 & 3 & 3 \\
\hline $\mathrm{S} 12$ & 0,5 & 3 & 3 & 3 & 3 & 3 & 3 & 3 & 3 & 3 & 3 \\
\hline \multicolumn{2}{|c|}{ Nilai Rata-rata } & 2,5 & 3 & 3 & 3 & 3 & 3 & 3 & 2,5 & 3 & 3 \\
\hline
\end{tabular}




\begin{tabular}{|c|c|c|c|c|c|c|c|c|c|c|c|}
\hline Subkriteria & $\begin{array}{c}\text { Bobot } \\
\text { Prioritas }\end{array}$ & Al & A2 & A3 & A4 & A5 & A6 & A7 & A8 & A9 & A10 \\
\hline S13 & 0,5 & 2 & 3 & 2 & 4 & 3 & 2 & 2 & 3 & 4 & 3 \\
\hline S14 & 0,5 & 2 & 3 & 2 & 2 & 3 & 2 & 2 & 3 & 3 & 3 \\
\hline \multicolumn{2}{|c|}{ Nilai Rata-rata } & 2 & 3 & 2 & 3 & 3 & 2 & 2 & 3 & 3,5 & 3 \\
\hline
\end{tabular}

Figure 7. Pedagogic Global Weight Ranking

\subsubsection{System analysis}

The analysis of the system that will be built is a system for Teacher Performance Assessment (PKG) by applying the Fuzzy Sugeno method. There are 4 input variables, namely Pedagogic, Personality, Social and Professional and 1 Output variable, namely the assessment result variable.

\subsubsection{System analysis for pedagogic variables}

Figure 8 is the equation used to analyze the pedagogic variables.

\begin{tabular}{|c|c|c|}
\hline & $1 ;$ & $\mathrm{x} \leq 1$ \\
\hline \multirow[t]{2}{*}{ Rendah $[\mathrm{x} 1]=$} & $(2-x) /(2-1)$ & $1 \leq x \leq 2$ \\
\hline & 0 & $x \geq 2$ \\
\hline & $1 ;$ & $\mathrm{x} \leq 1$ atau $\mathrm{x} \geq 3$ \\
\hline \multirow[t]{4}{*}{ Sedang $[\mathrm{x} 2]=$} & $(x-1) /(2-1)$ & $1 \leq x \leq 2$ \\
\hline & $(3-x) /(3-2)$ & $2 \leq x \leq 3$ \\
\hline & 0 & \\
\hline & 0 & $x \leq 2$ \\
\hline \multirow[t]{2}{*}{ Tinggi $[\mathrm{x} 3]=$} & $(x-2) /(4-2)$ & $2 \leq x \leq 3$ \\
\hline & 1 & $x \geq 3$ \\
\hline
\end{tabular}

From the equation in Figure 8, the form of the membership function of the first input of fuzzy analysis in the analysis of teacher performance evaluation is still ambiguous to be used as a basis for decision making, from the equation above, the form of the fuzzy membership function is designed as shown in Figure 9.

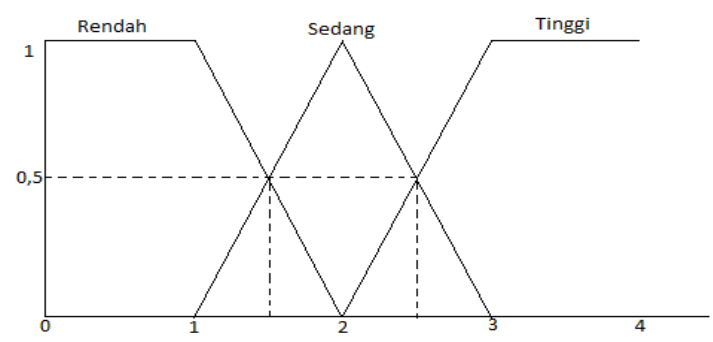

Figure 9. Rule Determination Process

Defuzzification in determining the way to solve the Sugeno method is by fuzzy modeling Sugeno Order Zero where the output is in constant form, to obtain defuzzification is done by finding the mean value.

\subsection{Implementation and Results}

The application of the Fuzzy Sugeno method to determine the results of teacher performance assessments into a computer application program using Matlab version 6.1. In this study, the analysis includes several stages, the Fuzzification process, the Inference process and the Defuzzification process . 
By testing the results of this analysis, the Matlab toolbox application used for the analytical testing stage can be done by running the program on Matlab, the application commands can be seen in Figure 10 .

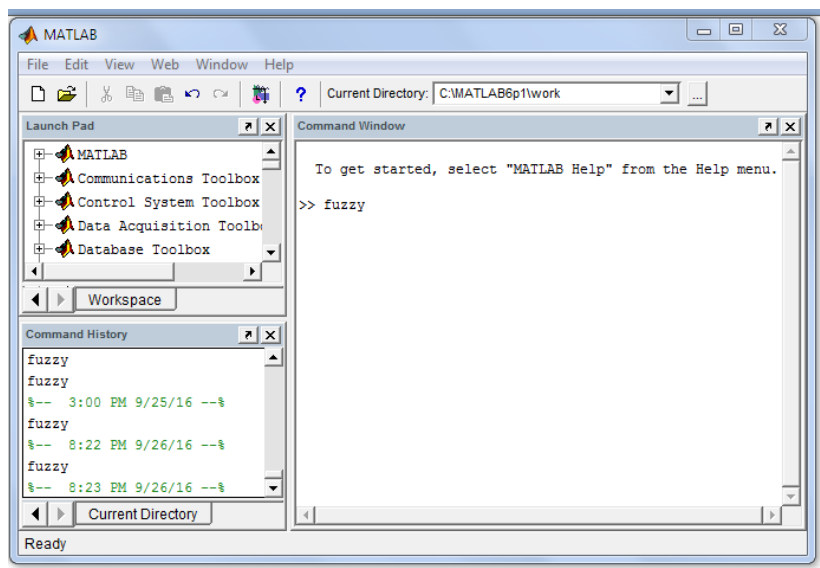

Figure 10. Command Line Display

After that press enter, the FIS Editor Toolbox Fuzzy display will appear as shown in Figure 11.

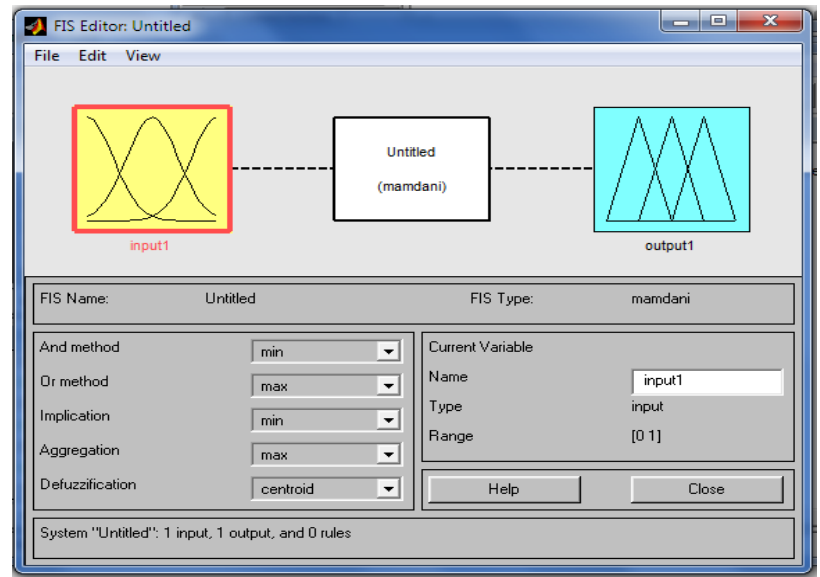

Figure 11. FIS Editor Toolbox Fuzzy Display

The variables in this study using randomization in data processing include four input variables, including education, personality, social and work, as well as the evaluation variable as an output variable. In this evaluation, the first step is to define the membership function. In Figure 12 and Figure 13 the following is a display of the Matlab version 6.1 program.

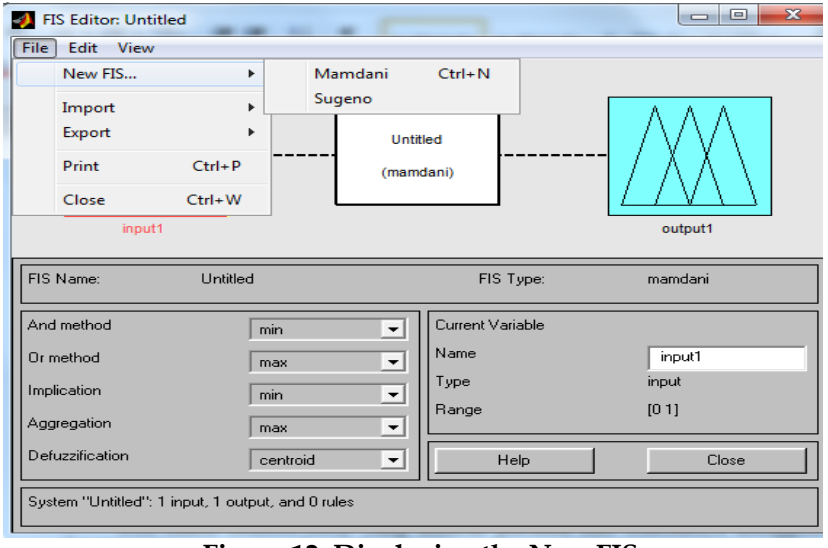

Figure 12. Displaying the New FIS 


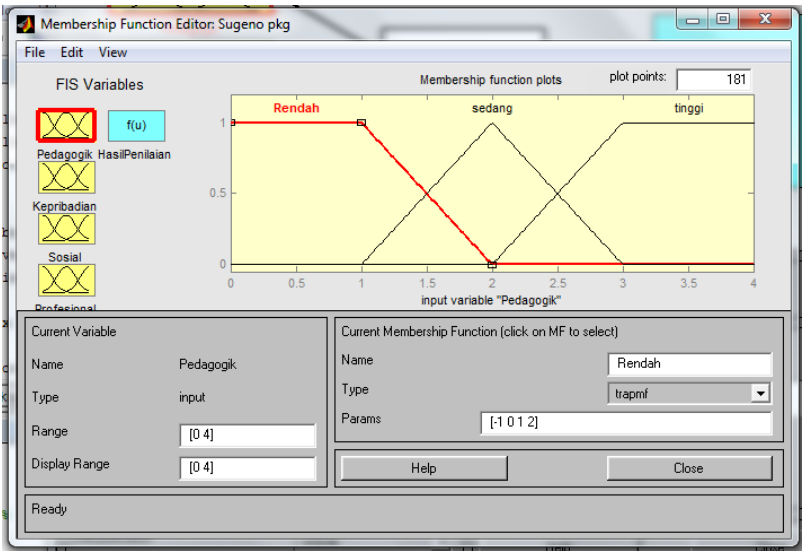

Figure 13. Pedagogic Variable Display

The inference process is a mapping of input parameters with output parameters. The input variables for the exact data needs from the variables of education, personality, social and work, are then processed by fuzzy inference program using the Sugeno method.

Several sections are needed in formulating the rules of inference, which indicate the synthesis and sections that indicate composition. From the three fuzzy inputs, we define the rules to be defined. The rules can be determined by the Pedagogic input variable, namely Low, Medium and High. At the same time, the output of the assessment results is Failed, Considered, and Passed. The settings are as in Figure 14.

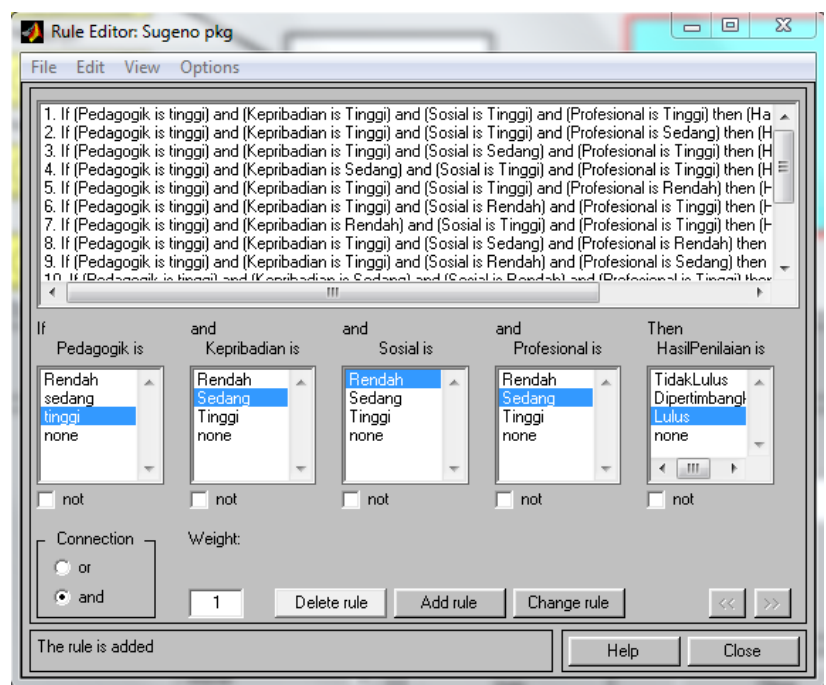

Figure 14. Sugeno Rules

At this stage of defuzzification, we can get exact values from teacher evaluation data. At the rule visualization stage, fuzzy result values will be obtained which have been converted into fuzzy logic . Figure 15 is the result of the view of the Sugeno method. 


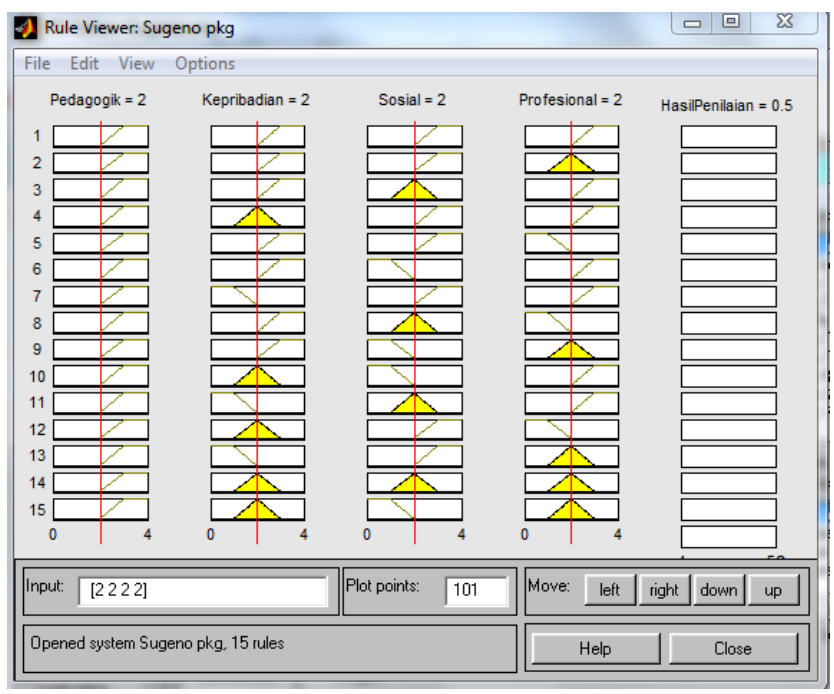

Figure 15. Rule Viewer Sugeno Method

\section{Conclusion}

From the results of research regarding the application of the Sugeno Method (Fuzzy Logic) for Teacher Performance Assessment, based on the required input, namely data on Pedagogic, Personality, Social and Professional variables, which were processed through the Fuzzy Inference system, it was found that the teacher's performance assessment was very good. It is indicated by the validity test comparing the calculation of manual results with the results of system calculations.

\section{References}

[1] Nursaka Putra. et al., 2020. Identification of Intelligent Participants Using Profile Matching Method (Case Study at Senior High School 1 Sungai Aur). , J. Phys.: Conf. Ser. 1842 012005. doi:10.1088/1742-6596/1842/1/012005.

[2] Achmad Noercholis dan Muhammad Luqman Hakim, 2016. Sistem Pendukung Keputusan Penilaian Kinerja Guru PNS Di SMKN Sukorejo 1 Dengan Menggunakan Metode Fuzzy AHP. , Jurnal Ilmiah Teknologi dan Informatika ASIA (JITIKA), Vol.10, No.2, Agustus 2016, ISSN: 0852-730X.

[3] Dadang Heksaputra, 2018. Fuzzy Intelligence System For Employee Assessment: A Case Studi Of Xyz University In Yogyakarta. , IJUBI - VOL. 1 NO. 1 (2018): 9 - 16.

[4] Wahyuni Havid, 2018. Penerapan Metode Fuzzy Logic Tsukamoto Untuk Penentuan Siswa Berprestasi Pada SMAN 1 Sangatta Selatan. , JATI (Jurnal Mahasiswa Teknik Informatika). Vol. 2 No. 1, Maret 2018.

[5] Fandra Satria dan Alexander J.P. Sibarani, 2020. Penerapan Metode Fuzzy Tsukamoto untuk Pemilihan Karyawan Terbaik Berbasis Java Desktop. , Jurnal Teknologi Informasi \& Komunikasi Digital Zone, Volume 11, Nomor 1 Mei 2020: 130-143. https://doi.org/10.31849/digitalzone.v11i1.3944.

[6] Fanisya Alva Mustika, 2021. Metode Fuzzy Sugeno Untuk Penilaian Kinerja Guru SMK Tamansiswa 3 Jakarta , STRING (Satuan Tulisan Riset dan Inovasi Teknologi). Vol. 6 No. 1 Agustus 2021. e-ISSN: 2549 - 2837. 